Nordisk Tidsskrift for Kriminalvidenskab 2005

\title{
VÅLdSutVECKLINGEN I Sverige 1974-2002 \\ - EN ANALYS AV SJUKVÅRDSDATA*
}

Av docent Felipe Estrada

In Sweden, as in many other European countries, violence constitutes an important focus for the public and political debate on crime. Much of what is said in the public debate, and done in the field of criminal policy, stems from a perception that violence is on the increase. This paper presents a new social indicator of trends in violence - Swedish hospital admissions resulting from acts of violence - and evaluates this measure in the light of more traditional indicators of violence - crime statistics, victim surveys and homicide statistics. The hospital data comprise 90,000 admissions from the period 1974-2002. The results show that admissions caused by violence were more numerous in the 1970s and 1990s than in the 1980s. Nothing in the hospital data indicates an increase in hospital admissions resulting from serious violent incidents over this period. No increase is noted in either fractures or knife and gunshot wounds. Thus, the continuous upward trend noted in crime statistics is not verified. Instead, the hospital data serve to verify the more stable trends indicated by victim surveys and homicide statistics. ${ }^{* *}$

Den mediala och politiska debatten kring våldsutvecklingen kännetecknas i alla nordiska länder av beskrivningar om en ständigt ökande våldsbrottslighet (Balvig 2000; Kivivouri et al 2002; Pollack 2001; Christie 2004). Våldet sägs också bli allt grövre inte minst genom en ökad vapenanvändning. Forskarvärldens analyser av våldsutvecklingen ger dock en mer splittrad bild. Omfattningen av våldsbrott är nämligen inte helt lätt att avgöra. Om en händelse $\mathrm{i}$ ett visst läge ska uppfattas som våld eller hot om våld är något som skiljer sig mellan olika situationer och grupper. Poliser, sjukvårdare, hemtjänstpersonal råkar mer eller mindre dagligen ut för händelser som i ett annat sammanhang skulle betraktas som våld eller hot om våld men som istället ses som incidenter som har med ens arbete att göra ( $\AA$ kerström 1997). För att ta ett mer tillspetsat exempel så uppfattar fångar en mängd händelser som normala $\mathrm{i}$ meningen att de inte ses som våldsamma eller hotfulla, en bedömning de flesta andra människor i samhället skulle göra (Nilsson 2002). Kort sagt är det oklart hur mycket våld och hot om våld som förekommer i ett visst samhälle i ett givet läge.

\footnotetext{
- Jag vill tacka Anders Karlsson vid EpC-Socialstyrelsen för all information om patientregistret. Jag har vidare fått värdefulla synpunkter från Hanns von Hofer, Leif Lenke och Anders Nilsson samt övriga deltagare vid kriminologiska institutionens seminarium och slutligen en anonym granskare. Alla felaktigheter i texten är självfallet mitt eget ansvar. Denna artikel bygger på en längre rapport som kan fås från författaren.

* Title in English: Swedish Trends in Violence According to Hospital Data. Original in Swedish.
} 
Vad som uppfattas som våld förändras också över tid. Det finns under de senaste decennierna en tydlig förändring i vårt samhälle mot en större känslighet för vad som ska uppfattas som våld och hur det skall kontrolleras ( $\AA$ kerström 1996; Estrada 1997, 1999; Balvig 2000; von Hofer 2000). Hanns von Hofer menar att detta inte minst manifesteras i lagstiftningen där en rad våldshandlingar som tidigare inte var lagstridiga i Sverige nu blivit det. 1965 kriminaliserades våldtäkt inom familjen, 1969 förbjöds proffsboxningen, 1979 förbjöds barnaga (von Hofer 2000:62). Sammantaget betyder detta att bedömare av våldets omfattning och utveckling måste arbeta med en rad olika indikatorer, kategoriseringar och avgränsningar. Tumregeln bland forskare är att ju lindrigare våldet är desto svårare är det att korrekt avgöra dess omfattning och utveckling.

I denna artikel kommer en hittills underutnyttjad indikator på våldsutvecklingen i Sverige att presenteras. Det handlar om offer för våld som blivit inskrivna för sjukhusvård åren 1974-2002 (se Brink et al 1997; Wladis et al. 1999; Wittebrood \& Junger 2002 samt Sivarajasingam et al 2003 för analyser av liknande data i Danmark, Sverige, Holland respektive England). Denna indikator är självfallet lika lite som andra indikatorer Det perfekta måttet. Antalet registrerade vårdtillfällen orsakade av våld täcker bara en del av allt det våld som sker och med all säkerhet främst det som kan karaktäriseras som allvarlig fysisk misshandel. Detta betyder att andra typer av våld - hot, hatbrott, rån, våld mot tjänsteman samt inte minst sexuellt våld - i princip utelämnas ur analysen om det inte leder till behandling inom sjukvården. Fördelarna med en serie som beskriver antalet behandlade våldsskador är dock uppenbar. Vi får ytterligare en indikator som kan jämföras och värderas sammantaget med de redan existerande. Antalet vårdtillfällen är dessutom ett mått som inte direkt styrs av synen på våld och hur det skall kontrolleras eller på viljan att göra ett polisärende av händelsen - med allt vad sistnämnda innebär för offret (se t ex Lindgren 2004).

\section{De traditionella indikatorernas bild av våldsutvecklingen i Sverige}

Kriminalstatistiken: väsentligt fler anmälda våldsbrott

Den bild som framträder av våldsutvecklingen utifrån kriminalstatistiken är tämligen entydig i de skandinaviska länderna - våldet har ökat. Och detta gäller såväl i ett längre som kortare tidsperspektiv (Balvig 2000; Westfelt 2001:66; von Hofer 2003a, 2004; Kühlhorn 2004). Ser man på den period som denna artikel fokuserar på, 1974-2002, så handlar det om en kraftig och i det närmaste kontinuerlig ökning av antalet polisanmälda misshandelsbrott. Hur denna kraftiga ökning ska tolkas är dock inte självklart givet att misshandelsstatistiken är känslig för förändringar av vad som uppfattas som brottslig våldsutövning och hur detta ska kontrolleras. Analyser av den uppmärksamhet som ägnats brottsligheten under de senaste decennierna visar entydigt att våldsbrott blivit en central fråga för media, myndigheter 
och politiska partier ( $\AA$ kerström 1996; Estrada 1997, 2004; Pollack 2001; Andersson 2002). Slutsatsen av denna forskning är att det sannolikt skett en utvidgning av vad som ska betraktas som en våldshändelse som är så allvarlig att den bör anmälas till polisen. Givet att det är välkänt att kriminalstatistiken inte är en direkt återspegling av utvecklingen av exempelvis våldshändelser utan snarare kan karaktäriseras som en "social produkt" - en handling som inte definieras, uppfattas som brottslig och därefter också anmäls, kan aldrig hamna i kriminalstatistiken (se t.ex. Coleman \& Moynihan 1996) bör kriminalstatistikens utfall jämföras med andra källor.

\section{Offerundersökningar: viss nivåförändring men ingen kontinuerlig ökning}

Offerundersökningar är trots välkända problem som selektivt bortfall, svårigheter att studera vissa typer av brott samt under- och överrapportering (se t ex. Nilsson 2002; Häll 2004) i mindre utsträckning än kriminalstatistiken påverkade av ändrad tolerans gentemot våld. Samtidigt måste det poängteras att en förändrad känslighet för våldsutövning också kan ha återverkningar på intervjupersoners benägenhet att uppge sådan utsatthet (Balvig 2000). I de fall där intervjupersoner uppger utsatthet för allvarligare våld som lett till mer entydiga konsekvenser är förändringar i synen på våld sannolikt ett mindre problem. Vanligen redovisas andelen av de intervjuade som uppgett att de utsatts. Beräkningar av antalet gånger som de intervjuade blivit utsatta kan också göras. Fördelen med sistnämnda presentationssätt är att det är mer jämförbart med statistiken över polisanmälda misshandelsbrott (Kühlhorn 2004). Nackdelen är emellertid att beräkningar av antal händelser är behäftade med mer allvarliga metodproblem (Häll 2004:38). Likaså spelar det stor roll vilken typ av våld som studeras. Det våld där offren uppger att de utsatts många gånger under ett år sker framförallt i anslutning till arbetslivet.

Den kraftiga ökningen av våldsbrottsligheten som kriminalstatistiken visar bekräftas inte av någon av de nordiska ländernas offerundersökningar om man ser till antalet utsatta personer (Olaussen 1995; Balvig 2000; Westfelt 2001; Stene 2003, 2005; Häll 2004; Heiskanen m.fl. 2004). Det är dock värt att notera att flera länders undersökningar visar på ökningar av utsattheten för våld eller hot i samband med yrkesutövning samtidigt som det vanligtvis grövre gatuvåldet är helt stabilt eller to m avtagande under de senaste 10-15 åren.

\section{Dödsorsaksstatistik: stabil nivå}

Dödsorsaksstatistik anses vanligen som en indikator med god validitet då det dödliga våldet jämfört med övriga våldshandlingar har ett väsentligt mindre mörkertal (se t. ex. Gustafsson \& Kühlhorn 1980:101; O’Brien 2003). Utifrån vilka som främst faller offer för dödligt våld bör kanske utvecklingen främst ses som en indikator på det mer allvarliga våld som förekommer bland utsatta grupper, vilka i 
mindre utsträckning deltar i offerundersökningar (Rying 2000; Petersson \& Rying 2004). Mot detta står dock det faktum att det i ett längre historiskt perspektiv finns ett tydligt samband mellan antalet fall av dödligt våld och lagförda för misshandel (von Hofer 2000, 2003a; O’Brien 2003).

Dödsorsaksstatistiken visar att det dödliga våldet inte ökat $i$ de nordiska länderna under de senaste decennierna (Balvig 2000:72; Westfelt 2001: 68; Petersson \& Rying 2004; von Hofer 2004). Detta förhållande tolkas vanligen som ett uttryck för att det allra grövsta våldet inte ökat under senare år. En intressant alternativ hypotes är dock att denna stabilitet främst är avhängig en förbättrad sjukvård där ett allt större antal av de allvarligast våldsskadade överlever (se t ex Gustafsson \& Kühlhorn 1980:103; Doerner 1988; Andersson 2004:138). Enligt Harris et al (2002) skulle antalet mord i USA ligga på en tre gånger så hög nivå (45 000-70 000 istället för 15000 -20 000) i slutet av 1990-talet än vad som faktiskt är fallet om inte det hade varit för förbättringarna i sjukvården. Utgångspunkten för detta antagande är den ökade klyftan mellan antalet anmälda misshandelsfall och antalet fall av dödligt våld. Vad Harris et al emellertid inte redovisar är utvecklingen av det faktiska antalet sjukvårdsbesök som föranletts av våld i USA, vilket självfallet vore det mest lämpliga sättet att studera hypotesen om sjukvårdens ökade betydelse. I föreliggande artikel finns dock en möjlighet att studera de sjukhusvårdade våldsfallen utveckling och detta under en period där trenderna mellan dödligt våld och anmälda fall av misshandel visar på motsvarande tudelning som den som Harris et al utgår från.

\section{Metod och material}

Sedan 1968 finns det i Sverige ett patientregister ${ }^{1}$ över personer som skrivits in och vårdats på offentliga sjukhus, dvs. det som brukar benämnas slutenvård, men det är först från år 1987 som registret är nationellt heltäckande. Alla patienter som söker vård på ett sjukhus och blir inskrivna för behandling registreras med personnummer, kön, ålder och vårdtillfällets längd. Alla skador som behandlas inom den slutna sjukvården ska dessutom ges en diagnos som beskriver skadans natur respektive en tilläggskod som beskriver vad som orsakat skadan eller sjukdomen. Sistnämnda variabel kallas för E-koden och det är alltså utifrån denna som våldshändelserna identifieras. Indelningen av E-koder görs sedan 1997 enligt den internationella ICD 10-klassifikationen. Perioden dessförinnan användes ICD 8 (1968-86) respektive ICD 9 (1987-96). Större förändringar i enskilda diagnoser som sker i anslutning till skiftena i patientregistrets klassifikationssystem (år 1987 respektive 1997) bör tolkas försiktigt.

En grundläggande felkälla för patientregistrets förmåga att fungera som indikator på våldsutvecklingen är förändringar i vårdsystemet som innebär att patienter placeras utanför eller innanför den slutna vården. Personer som drabbas av våld och 
som enbart vårdas inom sjukhusens akutmottagningar, öppenvård, vårdcentraler, jourmottagningar, skolhälsovård, tandläkare etc. ingår inte i statistiken om behandlingen inte lett till inskrivning. Det finns idag inga säkra uppgifter på hur stort detta mörkertal är. Analyser av allt vårdutnyttjande vid hem- och fritidsolycksfall visar dock att omkring var sjunde skada $(14 \%)$ ledde till inskrivning och att andelen inskrivna ökade tydligt för de våldsskador som hade allvarliga konsekvenser för offret. Liknande siffror framgår av lokala studier i Stockholm. 13 procent av de patienter som sökte vård för våldsskador och 40 procent av de knivskadade blev inskrivna $\mathrm{i}$ slutenvården (Wladis et al 1999; Boström et al 2000).

Ett sätt att studera i vilken utsträckning det kan ha skett förändringar av sannolikheten att en våldskada blir behandlad inom eller utanför slutenvården är att se på hur många vårdtillfällen som totalt registrerats i den slutna vården. Mellan 1974 och 1994 ökade antalet registrerade vårdtillfällen kraftigt (från 900000 till 1,7 miljoner per år), därefter skedde en viss minskning och de första åren på 2000-talet har antalet rapporterade vårdtillfällen legat på cirka 1,5 miljoner. Värt att notera är att den genomsnittliga tid som varje enskilt vårdtillfälle tar i anspråk har minskat tydligt under perioden. I klartext betyder det att fram till mitten av 1990-talet tog den slutna vården emot allt fler patienter, en utveckling som delvis möjliggjordes genom att kortare vårdtider frigjorde resurser. Detta betyder också att utvecklingen av vårdtiden respektive vårdtillfällen delvis ska ses som olika företeelser. Givet den diskussion som förs om betydelsen av ökad sjukvårdstillgång för utvecklingen av dödligt våld (Harris et al 2002) är det i sig ett intressant faktum att de våldsskadade patienterna, åtminstone i Sverige och England, utgör en mycket liten andel (ca 2\%) av dem som skrivs in för vård (Sivarajasingam et al 2001:106).

Ett annat problem är det interna bortfallet i patientregistret. Bortfallet i variablerna kön, ålder, vårdtid och diagnos är mindre än 1 procent. I omkring fem procent av vårdtillfällena saknas uppgifter hur skadan uppstått (dvs E-kod saknas). En stor del av detta bortfall beror på enskilda landstings sämre rapportering åren 1974-5, 1984-6 samt 1997-2000. För att motverka effekter av variationer i bortfall baseras resultaten på uppvägda tal. Antagandet bakom viktningen är att de fall som har E-kod och de som saknar detta inte skiljer sig systematiskt åt, något som stöds av den följsamhet som åren med låga bortfall visar med de i tid närliggande åren med höga bortfall (Estrada 2005). I patientregistret, precis som i andra register, finns ett mått av osäkerhet i kodningsarbetet. Skador som orsakats av våld kan kodas som osäkra fall eller som självtillfogade vilket leder till en underrapportering. Det finns dock inget som talar för att storleken på denna felkälla förändrats över tid. Att det finns ett omvänt problem med ökad rapportering över tid kan inte heller uteslutas. Den större uppmärksamheten kring våldsproblemet och den ökade kunskapen om våldets konsekvenser kan leda till en större ihärdighet att korrekt klassificera skador som orsakats av våld. 


\section{Materialet}

Analysen av våldsutvecklingen bygger på de regioner som lämnat uppgifter till patientregistret sedan år 1974. Urvalet står för en stor del av samtliga rapporterade våldshändelser de år då uppgifter finns från samtliga regioner (dvs. 1987-2002) och bedöms därför riksrepresentativt. Det uttag som gjorts ur patientregistret bygger på alla vårdtillfällen (dvs. inte antal patienter) där skadan orsakats av avsiktligt våld. Det finns en stor mängd diagnoser som de våldskadade offren fått. I artikeln särredovisas därför enbart ett mindre urval av alla diagnoser. Målsättningen har varit att skilja ut ett antal entydiga kategorier som återspeglar skador som oavsett behandlingsideologi, teknisk utveckling och organisation är så pass allvarliga att de med stor sannolikhet krävt en omfattande vårdinsats och således lett till inskrivning. Indelningen skiljer ut fem olika typer av våldsskador. De första tvåbeskriver skador orsakade av skjut -respektive stickvapen. Den enskilt största diagnosen, hjärnskakning, har kategoriserats för sig. I den fjärde kategorin urskiljs våld som lett till frakturer (t. ex näsben, käkben, revben, armar), dvs. vad som kan betraktas som allvarliga fysiska konsekvenser av våld utan vapen (se t ex Wikström 1990:40; Wladis et al 1999). I den femte gruppen har resterande skador hamnat. Sistnämnda kategori innehåller därmed en blandning av skador, både mer ytliga (blåmärken) men också sårskador och mer allvarliga skador på de inre organen. Kategorin "övriga skador" kan därför ses som en tämligen heterogen men samtidigt genomsnittlig grupp vad gäller allvarsgrad och vårdbehov.

\section{Våldsskador som lett till inskrivning på sjukhus}

Innan utvecklingstrenderna i patientregistret analyseras ska de sammantagna uppgifter som finns tillgängliga i patientregistret åren 1968-2002 redovisas. ${ }^{2}$ De aspekter som är möjliga att beskriva är offrens kön och ålder, var händelsen inträffat, vårdtidens längd samt våldets grovhet $i$ termer av vapenförekomst och skadediagnos. Härigenom erhålls en genomsnittlig bild av de våldshändelser som lett till slutenvård i Sverige. Denna bild kommer att jämföras med andra tillgängliga våldsindikatorer för att på så sätt närmare avgränsa vilken typ av våld som patientregistret främst innehåller.

\section{Kön och ålder}

Åren 1968-2002 finns 89760 vårdtillfällen orsakade av misshandel m.m. registrerade i patientregistret. Av dessa har 77 procent drabbat män och 23 procent kvinnor. I offerundersökningarna råder en förhållandevis jämnare fördelning av utsatthet för våld eller hot mellan könen (Estrada \& Nilsson 2004; Häll 2004). Kvinnors utsatthet handlar dock till större delen av hot om våld inom hemmet eller $\mathrm{i}$ arbetslivet, dvs. handlingar som inte kommer att synas i patientregistret (Estrada \& Nilsson 2004:173). Om man istället ser till andelen i offerundersökningar som 
uppgivit att de utsatts för våld som lett till sjukvårdsbesök så är fördelningen mer lik den som framkommer i patientregistret. Åren 1988-1999 utgjorde männen cirka 70 procent av dem som uppgett att de utsatts för sådant våld (ibid). Könsskillnaden i grövre våld bekräftas också av de mönster som framkommer i det dödliga våldet. Omkring $2 / 3$ av mordoffren är män och de flesta av dessa har dödats av någon utanför familjen. För kvinnorna finns gärningsmannen oftast inom familjen (Petersson \& Rying 2004). Medianåldern bland de sjukhusvårdade offren är 31 år och över hälften av offren befinner i åldersspannet 16-34 år. Kvinnornas utsatthet är jämnare spridd över livscykeln medan männen har en tydlig topp runt 20 års åldern. Detta mönster stämmer väl överens med offerundersökningarnas uppgifter beträffande utsatthet för våld som krävt någon form av vård (Häll 2004:42). Sammantaget bekräftar alltså andra tillgängliga datakällor de huvudmönster avseende grundläggande offerkaraktäristik som framträder i patientregistret.

\section{Vårdtid och skadans grovhet}

Den genomsnittliga våldsskadan i patientregistret har renderat en vårdtid på närmare 4 dagar (median 2 dagar) vilket tyder på att det våld som täcks är av allvarlig sort. Noterbart är dock att i närmare vart femte fall (16 534 vårdtillfällen) har utskrivningen skett samma dag som inskrivningen. Hur pass allvarligt våld som drabbat de sjukhusvårdade våldsoffren kan studeras dels genom att man ser till förekomsten av skador orsakade av skjut- respektive stickvapen, dels genom en analys av skadornas diagnos. Under perioden 1968-2002 finns 7108 vårdtillfällen registrerade där vapen (främst knivar) orsakat den behandlade skadan. Användning av vapen är alltså generellt sett ovanligt vid våldshändelser som leder till sjukvård (se också Boström et al 2000). Vapenskadorna uppvisar en klart längre vårdtid än övriga våldshändelser. Offer som vårdas för skottskador är inskrivna i genomsnitt dubbelt så lång tid som en misshandelsskada utan vapen (7,3 mot 3,7 dagar). Knivskador hamnar däremellan (4,8 dagar).

I tabell 1 framgår våldshändelserna uppdelade efter våldets grovhet. Vi kan se att det finns påtagliga skillnader i genomsnittlig vårdtid beroende på typen av våldsskada. Våldshändelser där offret har fått en hjärnskakning leder till förhållandevis kort vårdtid och utgör dessutom ensamt en stor andel av de händelser som lett till inskrivning (28\%). Skottskadorna är som påtalats de som kräver längst vårdtid men är samtidigt ovanliga. De våldshändelser som lett till frakturskador (32 \%) kräver en ungefär lika lång vårdtid som knivskador. Detta gäller i princip oavsett åldersgrupp även om frakturskadorna har en tendens att kräva en längre tids behandling för de allra äldsta offren (som å andra sidan inte är så många). Restkategorin "övriga skador" kräver en något kortare vårdtid än kniv- och frakturskadorna men påtagligt längre än hjärnskakningar. 
Tabell 1. Våldhändelser i patientregistret fördelade efter våldets grovhet, offrets kön och vårdtid (antal dagar i genomsnitt). 1968-2002.

\begin{tabular}{lccccc}
\hline & $\begin{array}{l}\text { Hjärn- } \\
\text { skakning }\end{array}$ & Frakturer & Knivskador & Skottskador & $\begin{array}{c}\text { Övriga } \\
\text { skador }\end{array}$ \\
\hline Vårdtid & 1,5 & 5,2 & 4,8 & 7,3 & 4,3 \\
Andel män (rad\%) & 79 & 81 & 86 & 77 & 68 \\
Andel kvinnor (rad\%) & $(29)$ & $(34)$ & $(8)$ & $(1)$ & $(28)$ \\
Medianålder & $(25)$ & $(27)$ & $(4)$ & 23 & $\begin{array}{c}32 \\
(43)\end{array}$ \\
\hline Totalt (\%) & 28 & 32 & 32 & 32 & 32 \\
\hline
\end{tabular}

Utvecklingen 1974-2002

Antalet behandlade våldsskador i slutenvård ökar under åren 1974-79 (figur 1). Därefter sker snabbt en tydlig minskning och under i princip hela 1980-talet är antalet behandlade våldshändelser på en stabilt lägre nivå än tidigare. Vid slutet av 1980-talet började dock antalet händelser öka och vid 1990-talet sker det en tydlig uppgång till de nivåer som rådde vid 1970-talets andra hälft. Efter 1997 framträder ett tydligt brott i serien. Åren 1998-2002 är nivån stabil men på en påtagligt lägre nivå än första delen av 1990-talet. Den fråga som nu självfallet måste analyseras är i vilken mån denna utveckling på ett godtagbart sätt kan ses som en indikator på det allvarliga våldets utveckling i Sverige.

Figur 1. Antal våldshändelser i patientregistret, 1974-2002.

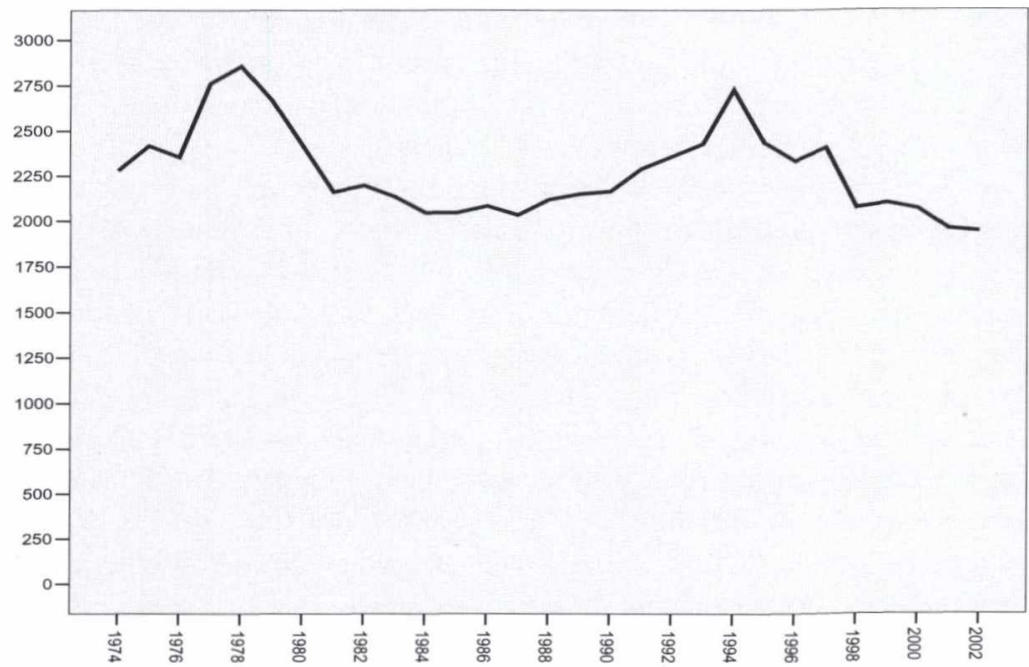


För den kommande tolkningen av de utvecklingstrender som framkommer i patientregistret är det intressant att se om det finns grupper som har en från huvudtrenden avvikande utveckling. Som tidigare påtalats drabbas olika grupper i samhället av olika typer av våld. Ett för alla grupper gemensamt utvecklingsmönster skulle därför kunna tas som ett uttryck för att det finns en systematisk felkälla i hur antalet vårdtillfällen som registreras i patientregistret utvecklas. De förändringar som framträder över tid skulle då främst kunna bero på exempelvis sjukvårdens kapacitet att ta emot patienter eller själva statistikföringen och inte på "utbudet" av våldsdrabbade. Om vi däremot kan se tydliga skillnader i utveckling mellan olika grupper, t.ex. att vissa ökar när andra är stabila eller minskar, så talar detta för att statistiken lyckas återspegla faktiska förändringar i omfattningen av våld hos olika grupper. En alternativ förklaring i sistnämnda fall kan dock också vara att de skillnader som syns främst är en effekt av förändrade prioriteringar.

\section{Kön och utveckling}

Grovt sett framträder ett likvärdigt huvudmönster för män och kvinnor - högre nivå på slutet av 1970-talet och första delen av 1990-talet respektive lägre på 1980-talet. Samtidigt bör man notera att kvinnorna med undantag för topparna åren 1978 respektive 1994 ligger tämligen stabilt på omkring 500 vårdtillfällen per år i de län som ingått i patientregistret sedan 1974. De kraftiga fluktuationer som återfinns i det totala materialet förklaras därför av att antalet vårdtillfällen för manliga offer ändrats kraftigt mellan olika perioder.

Figur 2. Antal vårdtillfällen pga.våld, efter kön, 1974-2002.

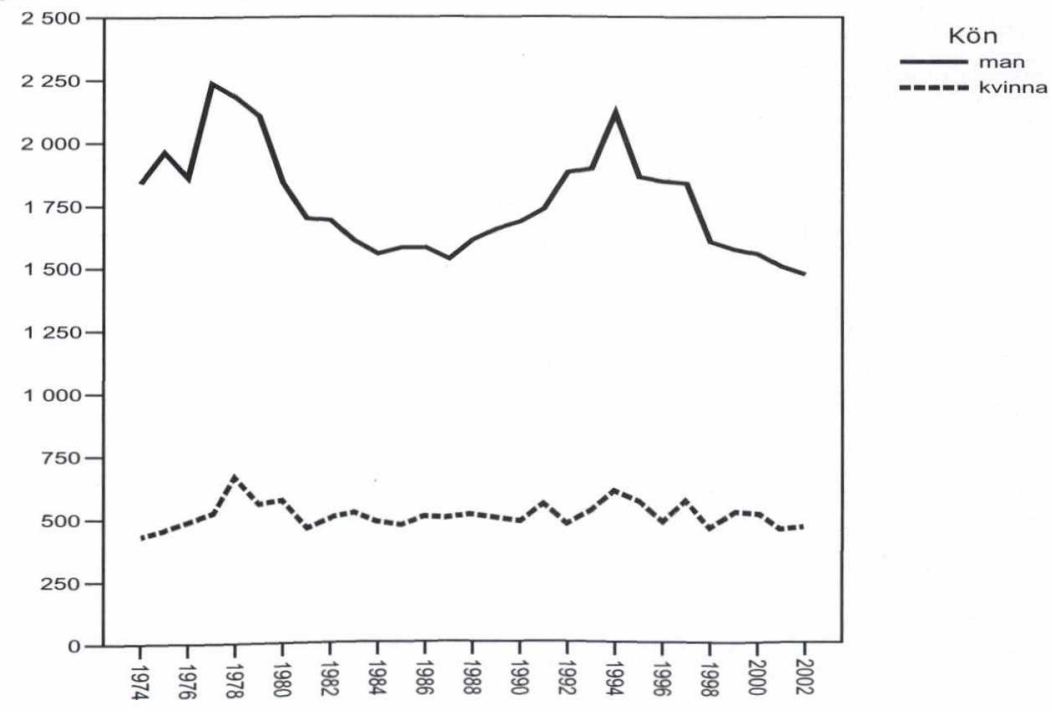




\section{Alder och utveckling}

Som tidigare nämnts är offren för våld som lett till inskrivning oftast i åldrarna 16-34. De grupper som täcker detta åldersspann styr genom sin relativa storlek huvudtrenden och de kraftiga ökningarna/minskningarna. Speciellt för åldersgruppen 25-34 sker en mycket kraftig minskning av vårdtillfällena under sista delen av perioden (se figur 3 nedan). Bland flera av de andra åldersgrupperna och då i synnerhet för de allra yngsta och äldsta offren sker inte alls samma tydliga minskning utan den förhållandevis högre 1990-tals nivån bibehålls.

\section{Alder, kön och utveckling}

Det verkar alltså som att den generella serien över behandlade våldshändelser innehåller undergrupper som har delvis skilda trender. I det följande ska utvecklingen för tre grupper som kan sägas utgöra offer för olika typer av våld studeras närmare:

- Barn i grundskoleåldern - drabbas oftast av "barnmisshandel" från föräldrar eller "skolvåld" från skolkamrater.

- Yngre vuxna - en grupp som till förhållandevis stor del består av ensamstående personer som deltar aktivt i nöjeslivet och därför löper hög risk att utsättas för "gatuvåld" från obekanta. För kvinnorna i denna åldersgrupp utgör dessutom "våld i hemmet" en betydelsefull kategori.

- Medelålders - personer i denna grupp drabbas ofta av "yrkesrelaterat våld".

Den intressanta frågan är nu om dessa grupper visar samma trender, vilket då lika gärna skulle kunna återföras på rapporteringsförhållanden som den faktiska utvecklingen. I figur $3 a$ och $3 b$ framgår att fem av dessa sex grupper uppvisar trender som skiljer sig från det generella mönster som redovisats tidigare. Dessutom finns det i flera fall skillnader mellan könen inom samma åldersgrupp. Både de kvinnliga offren i grundskoleåldern och kvinnor i medelåldern uppvisar från 1990 en något högre utsatthetsnivå än de hade tidigare, inklusive andra halvan av 1970-talet. Utvecklingen för kvinnor i åldern 25-34 står här i tydlig kontrast genom den såväl kraftiga som kontinuerliga minskning som framträder. Även de manliga offren i åldern 25-34 minskar tydligt, dock inte lika kontinuerligt som kvinnorna. De manliga offren i skolåldern ligger i sin tur tämligen stabilt, speciellt under 1990-talet, och om någon trend ska urskiljas för denna grupp så handlar det om en svag minskning sedan slutet av 1970-talet. De medelålders männen visar slutligen en trend som påminner om huvudkurvan. 
Figur 3a. Kvinnor, antal våldshändelser i tre olika åldersgrupper.

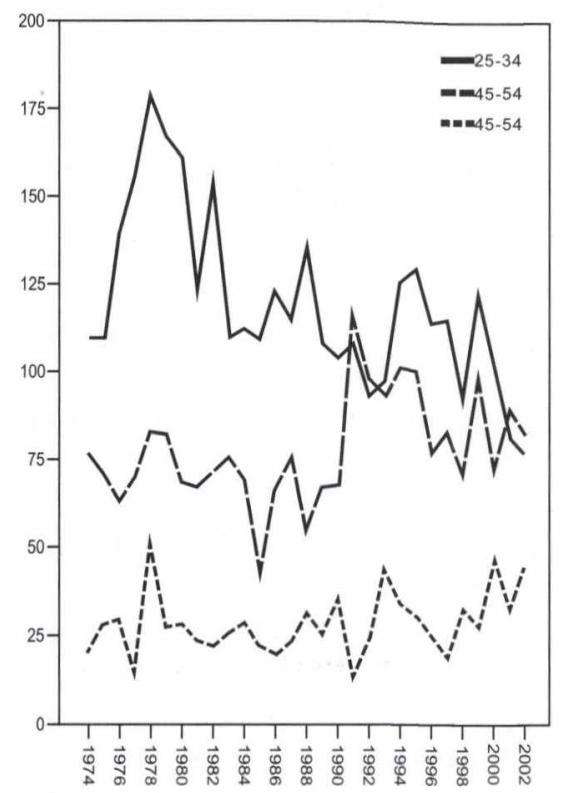

Figur 3b: Män, antal våldshändelser i tre olika åldersgrupper.

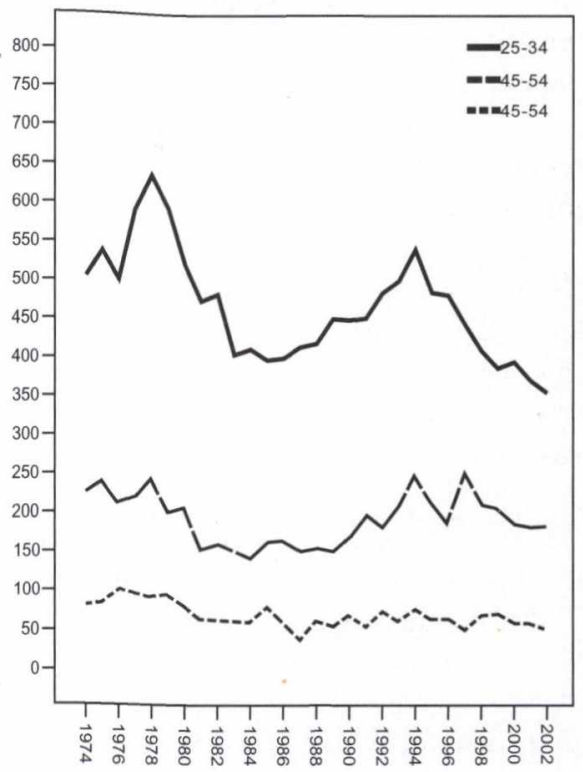

I Figur 4 redovisas utvecklingen av diagnoserna för hjärnskakningar, frakturskador, vapenskador samt "övriga skador". Vi har tidigare sett att skottskador generellt leder till de längsta vårdtiderna, vilket kan tolkas som att denna typ av händelser med stor sannolikhet leder till inskrivning för behandling inom slutenvården. Antalet våldshändelser orsakade av skottskador ligger stabilt under hela perioden. För knivskadorna gäller att nivån är helt stabil åren 19741996. 1997 sker en plötslig och kraftig förändring då antalet händelser som klassificerats som orsakade av knivvåld nästan fördubblas (från 132 till 249). En sannolik förklaring är att detta beror på förändringen av klassifikationssystemet (från ICD 9 till 10) som skedde just detta år. Det faktum att den stabila trenden fortsätter efter klassifikationsförändringen talar också för en sådan tolkning. 
Figur 4. Antal våldshändelser som lett till olika typer av skador. Frakturer, hjärnskakning respektive övriga skadediagnoser samt antal händelser där vapen har föranlett skadan. 1974-2002.

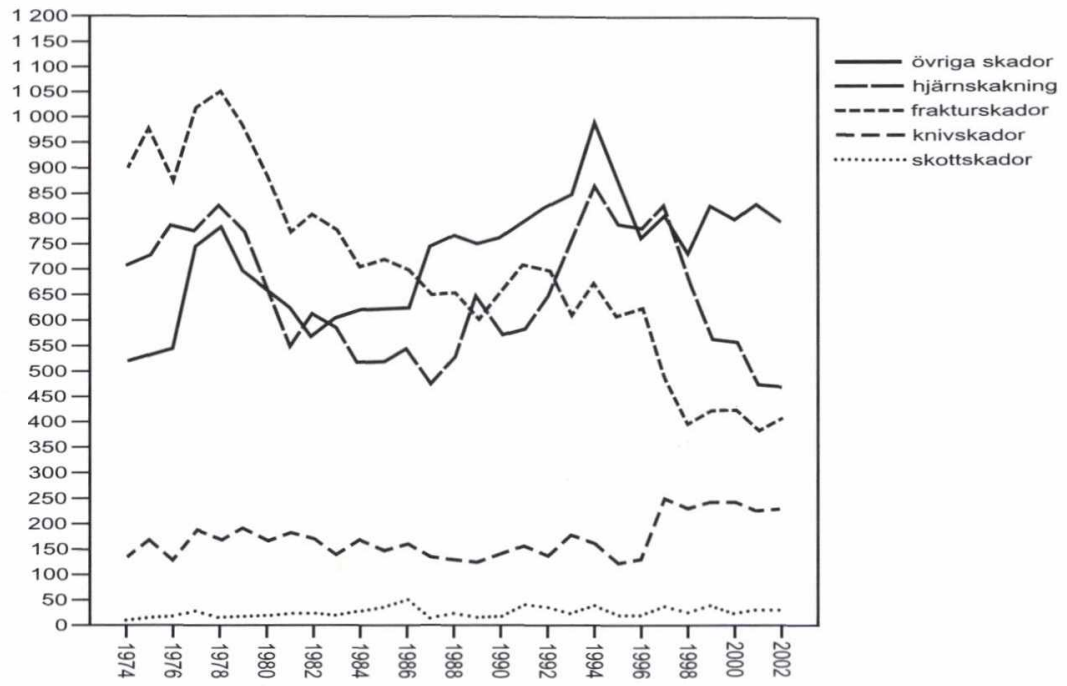

När man ser på utvecklingen av de övriga skadediagnoserna să kan man konstatera att det skett kraftiga förändringar. Från redovisningen av vårdtider vet vi att näst efter vapenskadorna hade frakturer de längsta vårdtiderna medan hjärnskakningar hade de klart kortaste. En frakturskada kan därför ses som ytterligare en indikator på en typ av händelser som i förhållandevis stor utsträckning leder till inskrivning för vård. Det är således intressant att antalet behandlingar av frakturer minskat påtagligt sedan slutet av 1970-talet. Minskningen sker i två steg. Under åren 1980-1990, dvs. under samma period som det totala antalet vårdtillfällen ökar i patientregistret (se ovan), sker en kontinuerlig minskning. Därefter kommer en period fram till 1997 där antalet behandlade frakturer ligger ganska stabilt. Sedan inträffar en omvänd situation jämfört med knivskadorna - dvs. mellan åren 1996/1997 minskar plötsligt antalet frakturer kraftigt för att sedan fortsätta ligga stabilt på den nya lägre nivån. Även här kan man misstänka att avvikelsen beror på klassifikationsförändringen. Antalet vårdtillfällen för hjärnskakning respektive "övriga skador" följer ungefär samma mönster som huvudtrenden som redovisas i figur 1 ovan. Antalet vårdtillfällen för dessa kategorier uppvisar sålunda en hög nivå vid slutet av 1970-talet. Under stora delar av 1980-talet är antalet inskrivningar lägre än åren 1977-79. Vid slutet av 1980-talet sker dock en tydlig ökning av hjärnskakningar och "övriga skador". Ökningen pågår fram till ett toppår 1995, därefter stabiliseras nivån på "övriga 
skador" till den höga nivå som gällde vid slutet av 1970-talet. Antalet slutenvårds behandlade hjärnskakningar minskar däremot kontinuerligt efter år 1995.

\section{Vårdtidens utveckling}

Den tid som våldskadorna behandlas har minskat påtagligt (figur 5). Under perioden 1974-1985 var det ovanligt att en patient skrevs ut samma dag som han/hon kommit in för behandling. Vanligast var istället att patienten låg kvar 1-2 dygn och det var nästan lika vanligt att skadan behandlades upp till en vecka. Som redovisats ovan finns det emellertid stora skillnader i vårdtid mellan olika skador där speciellt hjärnskakningarna skiljer ut sig genom förhållandevis korta vårdtider. Om dessa exkluderas (redovisas ej i figur) blir det än tydligare att våldsskador i början av perioden vanligtvis behandlades under flera dagar. Vid senare delen av 1980-talet förändras dock vårdtiden tydligt. Samtidigt som antalet behandlade våldsskador börja öka igen vid denna period blir de korta vårdtiderna vanligare. Vid slutet av perioden är det inte längre så ovanligt att en våldskadad patient skrivs ut samma dag som skadan inträffat. Det som dock i huvudsak förklarar minskningen av den genomsnittliga vårdtiden är att det sker en kraftig minskning av antalet händelser som leder till längre tids inskrivning. Detta mönster gäller också när man tittar på mer allvarliga skador som frakturer och vapenskador (redovisas ej i figur). Bland exempelvis de vapenrelaterade skadorna finns det en tydlig minskning av de allra längsta vårdtiderna samtidigt som de korta (främst 1-2 dagar) ökar.

Figur 5. Antal inskrivna dygn pga. våldshändelser 1974-2002.

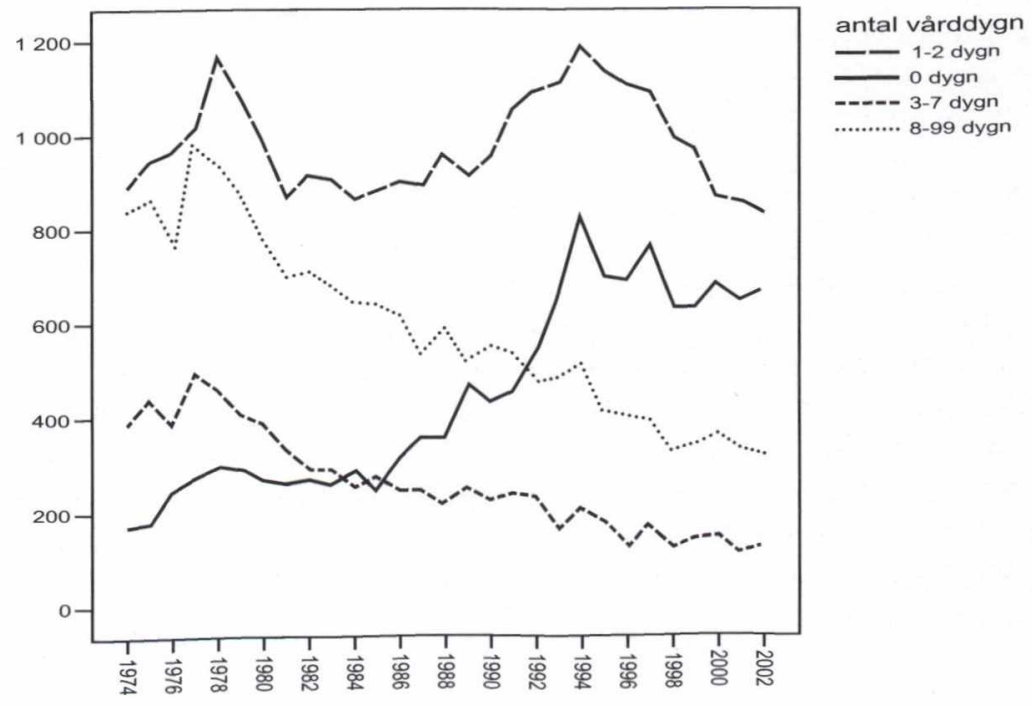


Sammantaget är det alltså sannolikt att det skett förändringar i sjukvårdens hantering av våldsskador. Vårdtiderna har minskat framför allt till följd av att allt färre händelser leder till långa inskrivningar inom slutenvården. Detta hänger i viss utsträckning samman med utvecklingen av de allvarligaste våldshändelserna. Sålunda har antalet frakturer som generellt leder till lång tids inskrivning minskat över tid. Samtidigt har vapenskadorna som är den kategori som kräver längst tids inskrivning inte minskat utan legat på en stabil nivå. Vårdtidens minskning kan därför inte förklaras med att våldets grovhet skulle ha minskat. Vad som istället är mer troligt är att både sjukvårdens möjligheter att på kort tid bedriva adekvat behandling ökat samtidigt som också effektivitetskraven skärpts. Bättre behandling och större krav på effektivitet leder till att patienter kan skrivas ut från slutenvård snabbare än tidigare, inte sällan samma dag som skadan inträffat. Inte desto mindre är det bland speciellt de mer allvarligt skadade offren (exkl. hjärnskakning) fortfarande ovanligt att man blir utskriven samma dag som man kommer in för behandling. Under åren 1998-2002 leder 83 procent av händelserna till inskrivning i minst ett dygn (genomsnittet för hela perioden är 92 procent). Vårdtidens minskning kan därför inte heller tas som intäkt för att offer som fått allvarligare skador överhuvudtaget inte blir inskrivna för behandling. Detta understryks av den generella utvecklingen som redovisades i metodavsnittet. Det totala antalet vårdtillfällen inom slutenvården har alltså ökat under stora delar av perioden samtidigt som vårdtiden minskat kontinuerligt.

\section{Diskussion}

I denna artikel har en underutnyttjad indikator över våldsutvecklingen analyserats. Utvecklingen av antalet i slutenvård behandlade våldsskador erbjuder ett komplement till de indikatorer som hitintills utnyttjas inom kriminologin. Det finns självfallet en mängd problem och felkällor kring denna indikator, härvidlag är det inte någon skillnad gentemot andra indikatorer som offerundersökningar och kriminalstatistik. Det tydligaste problemet är mörkertalet. De våldskador som leder till inskrivning inom den slutna sjukhusvården utgör enbart en mindre del av all av vården behandlat våld i Sverige. Merparten av de offer som söker vård för sina våldskador hanteras av den öppna vården i sjukhusen, vårdcentraler, jourcentraler, skolhälsovården etc. Det finns för närvarande ingen möjlighet att avgöra precis hur stort detta mörkertal är. Det vore värdefullt om framtida forskning kunde belysa detta.

Den sammantagna bild som framträder när man ser på de närmare 90000 våldshändelser som finns registrerade i patientregistret under perioden 1968-2002 bekräftar till stora delar de demografiska mönster som framkommer vid analyser av andra datakällor om våld. Den utveckling av det allvarliga våldet som indikeras 
av sjukvårdsdata är dessutom inte lätt att tolka i termer av prioriteringar inom sjukvården eller andra felkällor som har med själva statistikföringen att göra. Varför skulle i så fall exempelvis kvinnliga offer i åldern 25-34 prioriteras ned i förhållande till män i samma respektive andra åldrar? Varför har antalet inskrivna kvinnliga skolbarn ökat något sedan 1970-talet jämfört med pojkarna? Vad patientregistret istället pekar på är en våldsutveckling som sett olika ut beroende på typ av våld och därmed också för olika offergrupper. Detta förhållande är något som delvis också framkommer i de skandinaviska offerundersökningarna. Utsattheten för våld $\mathrm{i}$ arbetslivet uppvisar ökningar under de senaste decennierna och då inte minst hos medelålders kvinnor (Häll 2004:58ff; se också Balvig 2000; Heiskanen m.fl 2004). Utsattheten för våld eller hot på allmän plats (gatuvåld) visar i sin tur inga ökningar utan snarare en minskande trend sedan 1990 -talets början (Häll 2004:61; Heiskanen m.fl 2004). Slutligen så visar de svenska och finska självdeklarationsundersökningar bland ungdomar i årskurs nio (14-15 år) att utsattheten för våld som lett till besök hos sjuksyster, läkare eller tandläkare legat stabilt för både pojkar och flickor sedan starten år 1995 (Ring 2003; Kivivouri \& Salmi 2005).

Genom en särskiljning av våldsskador med olika skadekonsekvenser och behandlingstider har det varit möjligt att följa utvecklingen för händelser med olika stor sannolikhet att bli behandlade inom den slutna vården. Den kanske mest intressanta skadekategorin utgörs av vapenskadorna. Både skador som orsakats av stick- och skjutvapen visar en stabil utveckling. Undantaget är den tydliga nivåförändringen som sker av knivskadorna i samband med klassificeringsomläggningen 1997. Vapenskadornas stabila nivå stämmer därmed mer överens med utvecklingen av det dödliga våldet än statistiken över anmälda försök till mord respektive misshandel, vilka ökat kraftigt och kontinuerligt sedan mitten av 1970talet (jfr Harris et al 2002 och O’Brien 2003).

En slutsats utifrån det som hittills framkommit är därför att antalet behandlade våldsskador inom den slutna vården trots alla tidigare påtalade felkällor i åtminstone grova drag lyckas återspegla det allvarliga våldets utveckling i Sverige. Rimligheten i detta ska slutligen analyseras genom dels en beräkning av antalet våldskador som tar hänsyn till den minskande vårdtiden, dels genom en direkt jämförelse med utvecklingen av den indikator som ligger närmast patientregistrets innehåll - utvecklingen av antalet personer som i offerundersökningar uppger att de utsatts för våld som lett till att de besökt någon form av sjukvård.

\section{Ett försök till validering av våldsutvecklingen}

När en ny indikator på ett svårmätt förhållande tas i bruk är det självfallet svårt att avgöra dess giltighet. Därför har resultaten genom hela artikeln jämförts med andra relevanta källor över det allvarliga våldets fördelning och utveckling. 
En indikation på att det skett förändringar i sjukvårdens hantering av våldsskador är den tydliga minskningen i vårdtid. Oavsett typ av skada finns det en minskning av de längsta vårdtiderna samtidigt som de kortare ökar. Antalet fall där patienten skrivs ut samma dag som denne kommit in har gått från att vara mycket ovanligt till ganska vanligt. Denna utveckling skulle kunna ses som ett uttryck för att kraven för inskrivning skärpts under studieperioden, dvs. att mörkertalet ökat.

Det finns dock förhållanden som talar mot en sådan direkt koppling mellan minskad vårdtid och minskad inskrivningsfrekvens. Faktum är att fram till åtminstone 1990-talets början så finns det inget som tyder på att mörkertalet för behandlade våldsskador ökar pga. minskad intagning i slutenvården, snarare tvärtom. Mellan 1974 och 1994 skedde en kontinuerlig ökning av antalet vårdtillfällen samtidigt som den totala vårdtiden minskat kontinuerligt sedan åtminstone år 1987 (Estrada 2005). I klartext betyder detta att utvecklingen av vårdtiden och antal vårdtillfällen delvis ska ses som olika företeelser.

Oaktat ovanstående invändning kan det ändock vara intressant att fundera på vad en kompensation för minskad vårdtid skulle göra för den trend som framkommit i rapporten. Den eventuellt minskande inskrivningen av våldsskadade patienter borde framför allt ha påverkat de våldshändelser som tidigare lett till korta vårdtider (dvs. 0-1 vårddygn) eftersom det är här det finns utrymme för behandling utan inskrivning. Minskningen i vårdtid för våldsskador som kräver förhållandevis längre tids behandling ( 2 dagar eller mer) bör i detta sammanhang vara mindre problematiskt eftersom dessa fall torde bli inskrivna - låt vara för en kortare tids behandling än tidigare. Vad vi kan vara tämligen säkra på är nämligen att de allvarligaste våldskadorna som vanligtvis kräver flera dagars behandling med stor sannolikhet finns med i patientregistret. Givet dessa förutsättningar skulle en kompensation över tid för minskningen av antalet skador som inte leder till inskrivning kunna göras.

Den beräkning som valts är enkel. För det första har alla våldshändelser som åren 1974-1989 lett till 0 vårddagar exkluderats från tidsserien samtidigt som samtliga händelser oavsett vårdtid ingår åren 1990-2002. ${ }^{3}$ Vad denna beräkning gör är alltså att kompensera för den eventualitet att händelser som tidigare hade korta vårdtider under 1990-talet inte blivit föremål för inskrivning. Utvecklingen av denna beräknade tidsserie över våldshändelser som lett till inskrivning vid slutenvård avgränsas sedan till åldersgruppen 16-74 år och jämförs slutligen med utvecklingen av antalet personer (16-74 år) som i offerundersökningar uppgett att de utsatts för våld som medfört att de besökt någon form av läkarvård (figur 6). 
Figur 6. Andelen 16-74 åringar som i offerundersökningar (ULF-data) uppgett att de utsatts för våld som krävt läkarvård under senaste året (varierar mellan 0,5 till 1,3 åren 1977-2002) samt beräknat antal sjukhusbehandlade våldshändelser bland 16-74 åringar som krävt minst ett vårddygn år 1974-89 samt oavsett vårdtid 1990-2002 (varierar mellan 1196 och 1752). Värden på Y-axel avsiktligt exkluderade.

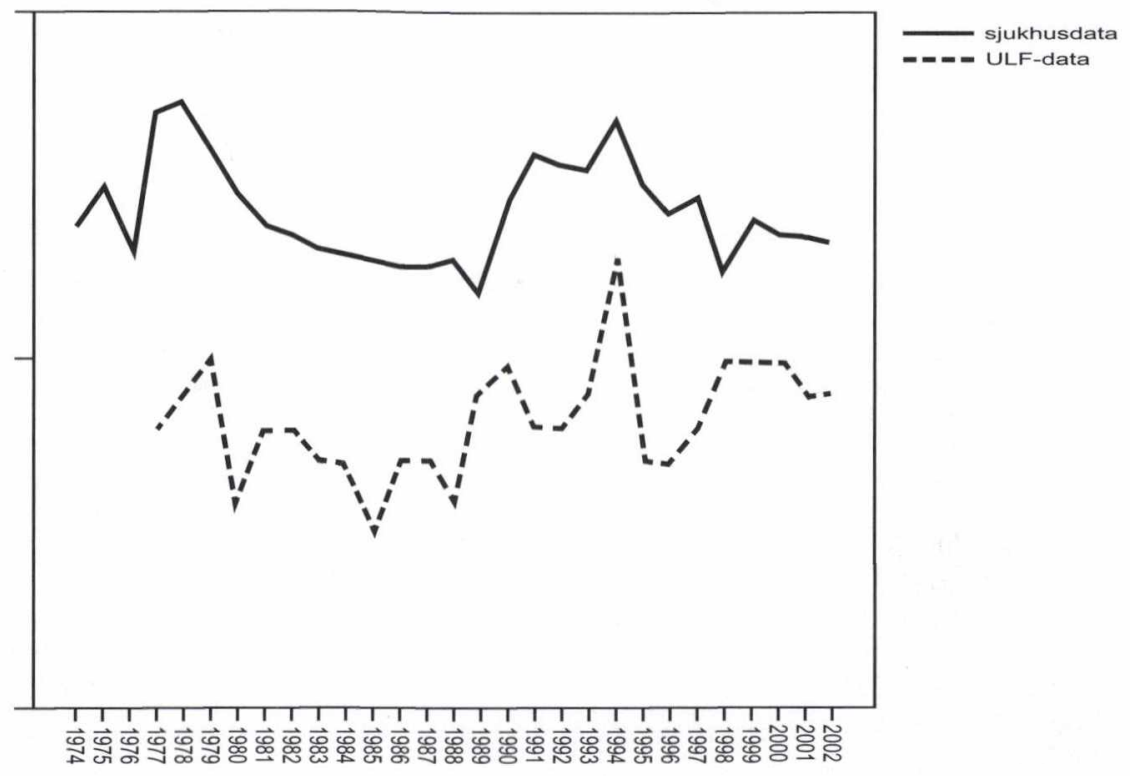

Jämförelsen av de två källor som beskriver våld som lett till sjukvård visar en förhållandevis samstämmig bild av utvecklingen. Båda serierna antyder att utsattheten för våld var hög i slutet av 1970-talet, att 1980-talet kännetecknas av en lägre nivå, att det sker en ökning de första åren av 1990-talet som innebär en återgång till de högre nivåer som rådde på 1970-talet samt att våldsutvecklingen efter tydlig topp kring 1994-95 stabiliserats under senare år. Ingen av serierna visar således att utsattheten för våld som lett till att offret uppsökt vård ökat kontinuerligt sedan slutet av 1970talet. Inte heller att det har skett en ökning under de allra senaste åren. Detta resultat är intressant för diskussionen om våldsbrottslighetens utveckling.

\section{Avslutning}

Inledningsvis konstaterades att olika datakällor ger skilda bilder av våldsutvecklingen. Med serien över antalet våldsskadade patienter som skrivits in för behandling inom sjukvården erhålls ytterligare en datakälla att ta hänsyn till, vilket självfallet måste ses som positivt. Givet den tämligen stabila nivå av våldsskador 
som behandlas inom slutenvården framstår ökningen av de polisanmälda misshandelsbrotten alltjämt som den enda tydliga indikationen på att våldsbrotten ökar i Skandinavien. Uppenbart är att sjukvårdsdata sällar sig till de indikatorer där inget stöd finns att hämta för att våldet $i$ våra samhällen skulle ha ökat påtagligt under framför allt de senaste 10-15 åren (se också Brink et al 1997 respektive Wittebrood \& Junger 2002 som redovisar motsvarande tendens i Danmark och Holland). Härmed blir det också tydligt vad de mest intressanta framtidsfrågorna blir för forskningen kring våldets utveckling i Skandinavien och andra jämförbara länder:

- Det första som bör konstateras är att forskningen om våldsutvecklingen i ett samhälle har mycket att vinna på att fortsätta ta fram nya indikatorer. Det är helt klart att det vore värdefullt om system kunde utvecklas för att få fram information om de våldshändelser som hanteras inom alla former av sjukvård. För tillfället finns bara enstaka lokala sådana datainsamlingssystem i Skandinavien.

- Trots att resultaten i denna studie går emot argumentet om att stabiliteten i dödligt våld beror på att sjukhusen klarar av att hantera fler allvarliga händelser (Gustafsson \& Kühlhorn 1980; Andersson 2004; Harris et al 2002) vore det värdefullt att ytterligare studera denna hypotes. Hur vanligt är det exempelvis att offren för dödligt våld omkommit innan sjukvården haft möjlighet att försöka rädda livet på offret? Hur många var det som tidigare dog efter det att ambulans kommit till platsen? Siffror för den korta perioden 1987-94 antyder inte att fler överlever i slutet av den studieperioden (Wladis et al 1999; Boström et al 2000). En analys av vad som ligger bakom den kraftiga ökningen av de anmälda våldsbrott som bedömts som försök till mord vore också värdefullt i detta sammanhang.

- Kühlhorn (2004) menar att bilden av en ökad våldsbrottslighet som framträder i kriminalstatistiken i stort sett är korrekt. Kühlhorn är medveten om betydelsen av de förändringar som skett beträffande synen på våld och därför fokuserar han på våldet mellan obekanta. Detta våld utspelar sig till stor del utomhus och har klara samband med det alkoholrelaterade nöjeslivet. Argumentet är att denna kategori generellt har en högre anmälningsbenägenhet och Kühlhorn menar att det därför inte är lika troligt att mörkertalet för denna typ av våld förändrats så mycket att det skulle kunna förklara den kraftiga ökningen av dessa anmälningar. Wikström (1990:40) och Estrada (1999:120) har genom studier av polisanmälda misshandelsfall visat att det mellan 1970-1987 respektive 1981-1997 skett en tydlig mörkertalsförändring av det polisanmälda misshandelsfallen i 
Stockholm. Det är anmälningar där offren har lindriga skador som ökar mest och som därmed står bakom huvuddelen av ökningen i statistiken. Anmälningar där våldet kan klassas som grövre ökar väsentligt långsammare och då främst åren 1970-87. Mot denna bakgrund vore det värdefullt om en motsvarande studie för våld mellan obekanta genomfördes.

- Kühlhorn (2004) menar också att offerundersökningarnas resultat stöder hans slutsats att de ökade polisanmälningarna om våld mellan obekanta återspeglar en faktisk ökning av det alkoholrelaterade gatuvåldet. Tolkningen baseras på att när man räknar på antalet händelser av våld (både lindriga, dvs. utan synliga märken och grövre) som intervjupersonerna säger att de utsatts för under de senaste 12 månaderna erhålls en ökning av antalet händelser. Det finns emellertid ett par problem här som bör studeras vidare. För det första är som tidigare nämnts osäkerheten i offerundersökningarnas uppgifter kring antal händelser givetvis större än uppgifterna om antalet personer som överhuvudtaget utsatts under senaste året. I den mån urvalet får med enstaka individer som rapporterar ett stort antal händelser kommer detta att väga tungt. En väsentlig fråga är därför hur fördelningen av den genomsnittliga ökningen av antalet händelser per utsatt individ ser ut. Är det en mycket liten grupp som rapporterar väsentligt fler händelser eller handlar det om en mer generell ökning $\mathrm{i}$ befolkningens utsatthet? Om ökningen beror på att den lilla grupp individer som uppger ett mycket stor antal händelser blivit något större blir tolkningen om en generellt högre våldsbrottslighet orsakad av en uppgång i alkoholkonsumtionen mer osäker. Mest problematiskt är emellertid att ökningen av antalet händelser till stora delar förklaras av våldet $\mathrm{i}$ arbetslivet samt $\mathrm{i}$ viss mån av våld $\mathrm{i}$ hemmet, två våldstyper där kopplingen till ökad alkoholkonsumtion kan finnas men inte är självklar. I kategorin där kopplingen är som mest självklar, gatuvåldet, visar offerundersökningarna i såväl Finland och Sverige en minskning snarare än en ökning det senaste decenniet (Häll 2004:61; Heiskanen m.fl. 2004). Så även om Kühlhorns hypotes att en ökad alkoholkonsumtion ligger bakom en ökad våldsbrottslighet är rimlig givet den historiska koppling som finns mellan den totala alkoholkonsumtionen och våldsbrott (Lenke 1990), återstår det att visa empiriskt för de allra senaste åren.

- Frågan om våldsutvecklingens koppling till övrig samhällsutveckling bör följaktligen studeras ingående. Alkoholpolitiken och alkoholkonsumtionen har genomgått stora förändringar under de senaste decennierna $\mathrm{i}$ Skandinavien (Room 2002). De senaste decenniernas sociala och ekonomiska utveckling har dessutom inneburit en ökad ojämlikhet såväl i 
Skandinavien som andra jämförbara västländer (Gottschalk \& Smeeding 2000; Palme et al 2002). Eftersom både alkoholkonsumtion och ojämlikhet i tidigare forskning visat sig vara relaterat till omfattningen och utvecklingen av våld finns det goda skäl att förvänta sig att dessa förhållanden ska slå igenom i våldsutvecklingen (se t ex Lenke 1990; Westfelt 2001). Samtidigt börjar det bli alltmer uppenbart att det är dags att en generell och kraftig ökning av våldet inte tas för given. Om den korrekta beskrivningen av våldsutvecklingen visar sig vara att den varit förhållandevis stabil under de senaste femton åren så reser detta förhållande flera teoretiskt intressanta frågor. En rimlig frågeställning är i vilken mån alkoholkonsumtionen har samma förklaringsvärde som tidigare i Skandinavien? Har en ökning av alkoholkonsumtionen olika betydelse beroende på konsumtionsmönstrets utveckling och hur har i så fall denna relation förändrats? När det gäller ojämlikhetens betydelse för våldsutvecklingen finns det resultat som antyder att bakom den stabila utsatthetsnivån för befolkningen i stort, döljer sig en ökad polarisering i utsattheten mellan olika samhällsgrupper (Nilsson \& Estrada 2003; Thacher 2004). En närliggande frågeställning som är väl värd att studera handlar om effekterna av den tilltagande socioekonomiska segregationen på områdesnivå, här är det mesta som gjorts baserat på amerikanska data (Sampson et al 2002; se dock Trickett et al 1995).

- Det finns, slutligen, uppenbarligen mycket som talar för att den bild av våldets utbredning och utveckling som media och den politiska debatten sprider inte är invändningsfri. Debatten om våldet som samhällsproblem tycks därmed åtminstone delvis ha en dynamik som inte direkt är kopplad till problemets utveckling. En intressant forskningsfråga är att försöka förstå såväl mekanismerna bakom en sådan situation som dess konsekvenser för politiken i allmänhet och kriminalpolitiken i synnerhet. Här finns redan en hel del intressant forskning som pekar på betydelsen av medias kommersialisering, det politiska systemets behov av handlingskraft pga. de legitimitetsförluster som skapats av välfärdspolitikens ifrågasättande, den minskande betydelse som expertkunskap ges inom kriminalpolitisk debatt, kvinnorörelsens inträde på den politiska arenan och dess fokusering på våldet som allvarligt problem (Hall et al 1978; Christie 1993; Beckett 1997; Åkerström 1998; Balvig 2000; von Hofer 2000; Garland 2001; Tham 2001; Andersson 2002; Estrada, 1997, 2004). Vad som behöver utredas tydligare är hur dessa olika förhållanden interagerar men kanske framför allt de konsekvenser som denna verklighetsbeskrivning har. Det finns oroande tecken på att de eventuellt goda förebyggande 
konsekvenser som ett ökat avståndstagande mot våld kan antas ha betalas genom en ökad polarisering i samhället där vissa samhällsgrupper, läs minoriteter, demoniseras som bärare av våldsproblemet (Hall et al 1978; Beckett 1997 Balvig 2000:32). Ett förhållande som enligt vissa forskare som yttersta konsekvens legitimerar ett ökat användande av institutionaliserat våld - fängelsestraffet (Waquant 2001; Melossi 2003; von Hofer 2003b).

\section{Litteratur}

Andersson, R. (2002): Kriminalpolitikens väsen. Avhandlingsserie nr 10, Stockholm: Kriminologiska institutionen, Stockholms Universitet.

Andersson, J. (2004): "Brottsutvecklingen i Sverige 1980-2003", Nordisk Tidsskrift for Kriminalvidenskab, 91: 132-143.

Balvig F. (2000): Det Voldsomme Samfund. Om vold som problem og faengsel som lösning. vol. 1 \& 2. Köpenhamn: Jurist- og Okonomforbundets Forlag.

Beckett, K. (1997): Making Crime Pay. Law and Order in Contemporary American Politics. Oxford: Oxford University press.

Boström, L. Heinius, G. \& Nilsson, B. (2000), "Trends in the Incidence and Severity of Stab Wounds in Sweden 1987-1994“, European Journal of Surgery, 166:765-770.

Brink, O., Charles, A.V., Sabroe, S., Jensen, J. and Sorensen, W. (1997): "Mindre Vold og Hyppigere Politianmeldelse", Nordisk Tidsskrift for Kriminalvidenskab, 84: 103-114.

Christie, N. (1993): Crime Control as Industry. Towards GULAGS, Western Style. London: Routledge.

Christie, N. (2004): En passende mengde kriminalitet. Oslo: Universitetsforlaget.

Coleman, C. \& Moynihan, J. (1996): Understanding Crime Data. Haunted by the Dark Figure. Buckingham: Open University Press.

Doerner, W. (1988): "The impact of medical resources upon criminally induced lethality: A further examination", Criminology, 26: 171-179.

Estrada, F. (1997): 'Ungdomsvåld: upptäckten av ett samhällsproblem. Ungdomsbrottslighet i svensk dagspress 1950-1994", Sociologisk Forskning, 34: 51-72.

Estrada, F. (1999): Ungdomsbrottslighet som samhällsproblem. Utveckling, uppmärksamhet och reaktion, Avhandlingsserie nr 3. Stockholm: Kriminologiska institutionen Stockholms universitet.

Estrada F (2004): "The Transformation of the Politics of Crime in High Crime Societies" European Journal of Criminology, vol 1:4:419-444.

Estrada, F. (2005): Våldsutvecklingen i Sverige -en presentation och analys av sjukvårdsdata. Working paper, Institutet för Framtidsstudier. Stencil. 
Estrada, F. \& Nilsson, A. (2004): 'Exposure to threatening and violent behaviour among single mothers - the significance of lifestyle, neighbourhood and welfare situation", British Journal of Criminology, 44:2:168-187.

Garland, D. (2001): The Culture of Control. Crime and Social Order in Contemporary Society, Oxford: Oxford University Press.

Gustafsson, M. \& Kühlhorn, E. (1980): "Våldsbrottsutvecklingen i kriminalsociologisk belysning" i Brottsutvecklingen, rapport 1980:3 s. 85-109. Stockholm: Brottsförebyggande rådet.

Hall S., Critcher C., Jefferson T., Clarke J. \& Roberts B. (1978): Policing the Crisis. Mugging, the State, and Law and Order. London: MacMillan.

Harris, A., Thomas, SH., Fisher, GA. \& Hirsch, DJ. (2002): "Murder \& Medicine: The Lethality of Criminal Assault 1960 - 1999", Homicide Studies 6:128-166.

Heiskanen, M., Sirén, R. \& Aromaa, K. (2004): Victimisation and fear in Finland 2003. National Research Institute of Legal Policy, Report 59. Helsingfors.

von Hofer, H. (2000): "Criminal Violence and Youth in Sweden: a Long-term Perspective", Journal of Scandinavian Studies in Criminology and Crime Prevention, 1/1, 56-72.

von Hofer, H. (2003a): "Crime and Punishment in Sweden. Historical Criminal Justice Statistics 1750-2000", Journal of Scandinavian Studies in Criminology and Crime Prevention, 4/2, 162-179.

von Hofer, H. (2003b): "Prison populations as political constructs: The case of Finland, Holland and Sweden", Journal of Scandinavian Studies in Criminology and Crime Prevention, 4/1, 21-38.

von Hofer, H. (2004): "Crime and Reactions to Crime in Scandinavia", Journal of Scandinavian Studies in Criminology and Crime Prevention, 5/2, 148-166.

Häll, L. (2004): Offer för vålds- och egendomsbrott 1978-2002. Rapport 104. Stockholm: Statistiska centralbyrån.

Kivivouri, J., Kemppi, S. \& Smolej, M. (2002): Etusivujen väkivalta (Front Page Violence, inkl. engelsk sammanfattning), Helsinki: National research Institute of Legal Policy.

Kivivouri, J. \& Salmi, V. (2005): "Trends of self-reported juvenile delinquency in Finland, 1995-2004", Publication 214, Summary. Helsinki: National research Institute of Legal Policy.

Kühlhorn, E. (2004): "Misshandel" i Brottsutvecklingen i Sverige 2001-2003. BRÅ-rapport 2004:3. Stockholm: Brottsförebyggande rådet.

Lenke, L. (1990): Alcohol and criminal violence - Time series analyses in a comparative perspective. Stockholm: Almqvist \& Wiksell international.

Lindgren, M. (2004): Brottsoffer i rättsprocessen. Akademisk avhandling. Stockholm: Jure Förlag AB. 
Melossi, D. (2003): “In a Peaceful Life': Migration and the Crime of Modernity in Europe/Italy", Punishment \& Society 5/4: 371-397.

Nilsson, A. (2002): Fånge i marginalen - uppväxtvillkor, levnadsförhållanden och återfall $i$ brott bland fångar. Avhandlingsserie nr 8. Stockholm: Kriminologiska institutionen Stockholms universitet.

Nilsson, A. \& Estrada, F. (2003): "Victimisation, Inequality and Welfare during an Economic Recession. A Study of Self Reported Victimisation in Sweden 1988-1999", British Journal of Criminology, 43, 655-672.

Olaussen, L.P. (1995): "Voldskriminalitetens utvikling de to siste tiårene", Nordisk Tidsskrift for Kriminalvidenskab, vol. 82: 97-116.

O'Brien, R.M. (2003): "UCR violent crime rates 1958-2000: recorded and offender-generated trends", Social Science Research, 32:499-518.

Palme, J., Bergmark, Å., Bäckman, O., Estrada, F., Fritzell, J., Lundberg, O. \& Szebehely, M (2002): "Welfare Trends in Sweden. Balancing the Books for the 1990's". Journal of European Social Policy, 12:329-346.

Petersson, L. \& Rying, M. (2004): "Dödligt våld", i Brottsutvecklingen i Sverige 2001-2003. BRA-rapport 2004:3. Stockholm: Brottsförebyggande rådet.

Pollack, E. (2001): En studie i Medier och Brott, Akademisk avhandling, Stockholm: Stockholms universitet, JMK.

Ring, J. (2003): Stöld, våld och droger bland ungdomar i årskurs nio. BRÅ-rapport 2003:5. Stockholm: Brottsförebyggande rådet.

Room, R. (2002): The effects of Nordic alcohol policies. What happens to drinking and harm when alcohol controls change? NAD rapport 42. Helsinki.

Rying, M. (2000): Dödligt våld i Sverige 1990-1996. LIC-uppsats. Stockholm: Kriminologiska institutionen, Stockholms universitet.

Sampson, R.J., Morenoff, J.D. \& Gannon-Rowley, T. (2002): “Assesing 'neighbourhood effects': social processes and new directions in research", Annual Review of Sociology, 28:443-78.

Sivarajasingam, V. \& Shepherd, J. (2001), "Trends in Community Violence in England and Wales 1995-1998: an Accident and Emergency Department Perspective" Emergency Medicine Journal, 18: 105-109

Sivarajasingam, V., Shepherd, J., Matthews, K. \& Jones, S. (2003), "ViolenceRelated Injury Data in England and Wales - An Alternative Data Source on Violence", British Journal of Criminology, 43: 223-227.

Stene, R. (2003): "Levekårsundersökelsene 1983-2001: Vold og trusler i 20 år", Samfunnsspeilet, 2003/1, 2-7.

Stene, R. (2005): “Kriminalitet. Ung utsatt og tatt”, Samfunnsspeilet, 2005/4, 83-94. 
Thacher, D. (2004): "The rich get richer and the poor get robbed: Inequality in US Criminal victimisation 1974-2000", Journal of Quantitative Criminology, 20:89-116.

Tham, H. (1995): 'Från behandling till straffvärde. Kriminalpolitik i en förändrad välfärdsstat", i Victor, D. (Red.), Varning för straff. Om vådan av den nyttiga straffrätten, s. 78-109. Stockholm: Fritzes.

Tham, H. (1999): "Lag och ordning som vänsterprojekt? Socialdemokratin och kriminalpolitiken”, i BRÅ (Red.), Atta reflektioner om kriminalpolitik, s. 96117. Stockholm: Brottsförebyggande rådet.

Trickett, A., Ellingworth, D., Hope, T. \& Pease, K. (1995): "Crime Vicitimisation in the Eighties", British Journal of Criminology, 35, 343-59.

Waquant, L. (2004): Fattigdomens fängelser. Stockholm: Brutus Östling, Symposion.

Westfelt, L. (2001): Brott och straff i Sverige och Europa. Avhandlingsserie nr 5, Stockholm: Kriminologiska institutionen Stockholms universitet.

Wikström, P.O. (1990): "Våldsbrott" i Brottsutvecklingen 1989. BR A-rapport 1990:9. Stockholm: Brottsförebyggande rådet.

Wittebrood, K. \& Junger, M. (2002): “Trends in violent crime: A comparison between police statistics and victimization surveys", Social Indicators Research, 59, 153-173.

Wladis, A., Boström, L. \& Nilsson, B. (1999), "Unarmed Violence-Related Injuries requiring Hospitalization in Sweden from 1987 to 1994" The Journal of Trauma, injury, infection and critical care, 47: 733-737.

Åkerström , M. (1996): “’Våldet' en moralisk panik? Emotionellt engagemang eller publika tyckanden?" i Åkerström, M. (red) Kriminalitet Kultur Kontroll, s. 226-244. Stockholm:Carlssons.

Åkerström, M. (1997): "Att anmäla våld - en praktik inom lokala kulturer" Nordisk Tidskrift for Kriminalvidenskab, 84:125-132.

\section{Noter:}

1 Registret administreras av EpC, Socialstyrelsen. En mer utförlig beskrivning av materialet och dess olika felkällor finns publicerad i Estrada 2005, vilken kan fås från författaren.

2 Eftersom jämförbarheten över tid inte är i fokus kan hela materialet utnyttjas.

3 Även analyser utifrån andra förutsättningar har genomförts men dessa förändras inte tidsseriens huvudtrender. För en mer utförlig beskrivning se Estrada 2005.

Adress:

Institutet för Framtidsstudier

Box 591

10131 Stockholm, Sverige 